\title{
“The Post-Modern Turn” of the US Military Scholars: Shallow, Adherent and Critical?
}

\author{
Loboda Yu. O., King's College London
}

According to historical facts, military elites were never totally separated from intellectual civil elites. From Ancient times to nowadays professional military education and personal contacts flourished due to mutual interest between these two parties. It is not easy task to define if this interaction was constructive or not for military since there is rich contradictory evidence - how stoics educated victorious Roman imperial army and how Henri Bergson's name is associated with two military blunders of France in the both world wars, despite of heavy criticism from his civil colleagues and generals in interwar period. Thus, it is important to understand, which intellectual biases and fashion are represented in contemporary Western military periodics and academic scholarship as a mirror of contemporary military thinking. The overall trend can be defined as "postmodernist turn", which is realized in the following three main forms: shallow, adherent and critical. The majority of military writers, being familiar with the leading civil intellectuals through their higher education in humanities and social science, apply for postmodernist agenda pursuing the general intellectual mainstream fashion, which is common for both civil and military publications. Nevertheless, in the majority of cases this happens due to shallow following mainstream narrative, not because of the personal priorities, when adherence to a specific intellectual fashion is well-grounded and clearly motivated. The same is applicable to the military criticism of postmodernism, when the critical approach refers to the deep competence in contemporary intellectual debates among civil experts. This approach mainly reproduces devastating criticism of postmodernism as relativist, a way of thinking which is not relevant to military profession. This situation can be quite fruitful both for military and civil academics: it creates perfect conditions for critical debates aimed for clearing out fashionable metaphors, popular mindsets and elements of narrative, where pure theoretic structures can face the trial of practitioners, whose professional decisions are extremely responsible for safety of human lives and national security. Anyway, the internal opposition to the supporters of postmodernism in military sciences gives hope that it has all the chances not to become an overwhelming trend in military scholarship.

Keywords: philosophy; humanities; intellectual fashion; military disciplines; postmodern culture; deconstructivism; social constructivism

\section{«Постмодерністський поворот» американських воєнних науковців: поверхневий, схвальний чи критичний?}

\section{Лобода Ю. О., Лондонський Королівський коледж}

Воєнна професія та освіта і наука ніколи не були повністю відокремлені одна від одної. Починаючи з епохи Античності, офіцери завжди контактували з цивільними інтелектуалами - особисто чи на інституційному рівні.

Поширення гуманітарної освіти серед офіцерів збройних сил країн Заходу визначається дослідниками як позитивний чинник, який поліпшує здатності військових до критичного мислення при виконанні службових обов'язків, розширює їхній світогляд.

Однак досі залишається невивченим питання, як саме зміст сучасної вищої гуманітарної освіти може впливати на бойові здатності офіцерів. Сучасна Західна освіта та інтелектуальна мода значно відрізняються від, наприклад, наукової основи діяльності стратегічних служб, закладених Шерманом Кентом - дедалі частіше у фаховій літературі можна зустріти посилання на такі поняття, як «релятивізм», «ризома», «соціальний конструкт» та інших, що можна віднести до лексикону «постмодернізму».

Лише в деяких випадках автори спеціалізованих воєнних видань демонструють достатню обізнаність в особливостях сучасних наукових та культурних напрямків, що дозволяє їм критично оцінювати інтелектуальну моду, яка поширюється і на воєнних науковців.

В статті були виокремлені такі способи рецепції постмодерністської тематики: поверхнева, схвальна та критична.

Дописувачі професійної воєнної періодики мають, як правило, і вищу гуманітарну цивільну, і фахову воєнну освіту. Не дивлячись на це, досить часто трапляються випадки некритичного чи необгрунтованого використання елементів постмодерністського наративу, що можна пояснити загальними тенденціями у воєнній публіцистиці та персональними уподобаннями дослідників. Щоправда, також наявна і критика постмодерністського «ухилу» у воєнній публіцистиці, де використовуються матеріали академічних дебатів, в яких беруть участь цивільні фахівці. 
Наразі можна стверджувати, що постмодерністські уподобання сучасних воєнних науковців та публіцистів - це здебільшого данина тенденціям інтелектуальної моди, а спротив цим тенденціям, який відображений у воєнній періодиці та фаховій літературі, вказує на вірогідність того, що ця інтелектуальна мода може не стати визначальною в царині воєнних дисциплін.

Ключові слова: філософія; гуманітарні дисципліни; інтелектуальна мода; воєнні дисципліни; культура постмодерну; деконструктивізм; соціальний конструктивізм

\section{«Постмодернистский поворот» американских военных ученых: поверхностный, одобрительный или критический?}

\section{Лобода Ю. А., Лондонский королевский колледж}

Военная профессия, образование и наука никогда не были полностью отделены друг от друга. Начиная с эпохи Античности, офицеры всегда контактировали с гражданскими интеллектуалами - лично или на институциональном уровне.

Распространение гуманитарного образования среди офицеров вооруженных сил стран Запада определяется исследователями как положительный фактор, который улучшает способности военных к критическому мышлению при выполнении служебных обязанностей, расширяет их мировоззрение.

Однако до сих пор остается неисследованным вопрос о том, как именно содержание современного высшего гуманитарного образования может влиять на боевые способности офицеров. Современное Западное образование и интеллектуальная мода значительно отличаются от, например, научной основы деятельности стратегических служб, заложенных Шерманом Кентом - все чаще в профессиональной литературе можно встретить ссылки на такие понятия как «релятивизм», «ризома», «социальный конструкт» и других, которые можно отнести к лексикону «постмодернизма».

Только в некоторых случаях авторы специализированных военных изданий демонстрируют достаточную осведомленность в особенностях современных научных и культурных направлений, что позволяет им критически оценивать интеллектуальную моду, которая распространяется и на военных ученых.

В статье были выделены такие способы рецепции постмодернистской тематики: поверхностная, одобрительная и критическая.

Корреспонденты профессиональной военной периодики имеют, как правило, и высшее гуманитарное гражданское, и профессиональное военное образование. Несмотря на это, довольно часто встречаются случаи некритического или необоснованного использования элементов постмодернистского нарратива, что можно объяснить общими тенденциями в военной публицистике и персональными симпатиями исследователей.

Тем не менее, также присутствует и критика постмодернистского «уклона» в военной публицистике, где используются материалы академических дебатов, в которых участвуют гражданские специалисты.

На сегодняшний день можно утверждать, что постмодернистские симпатии современных военных ученых и публицистов - это преимущественно дань тенденциям интеллектуальной моды, а сопротивление этим тенденциям, которое отражено в военной периодике и профессиональной литературе, указывает на вероятность того, что эта интеллектуальная мода может не стать определяющей в сфере военных дисциплин.

Ключевые слова: философия; гуманитарные дисциплины; интеллектуальная мода; военные дисциплины; культура постмодерна; деконструктивизм; социальный конструктивизм

$\mathrm{T}$ This very fashionable quotation (which is sometimes erroneously ascribed to Thucydides) roams from one article written by military scholar to another: 'The nation that will insist upon drawing a broad line of demarcation between the fighting man and the thinking man is liable to find its fighting done by fools and its thinking by cowards' [4, p. 85]. Actually, in European history the division between civil academics and military professionals happened not so often. Ancient philosophers educated Greek and Roman generals (emperors Marcus Aurelius and Julian were philosophers); in I-II AD stoic philosophy dominated in Roman society and its army as well; Prince Eugene of Savoy treated Leibnitz' "Monadology" as a sacred writing [27, p. 202]; pre-Great War French generals obtained a name of "bergsonians", in the Soviet Military universities the Marxist-Leninist philosophy was compulsory course. Modern military specialists cannot avoid completely familiarization with contemporary intellectual culture, especially when it turns to a fashion. They read books and papers, they have their personal scientific interests, they receive professional education which to some extent reflects contemporary intellectual debates. 
It is very complicated question in which way this influence, especially represented by leading public intellectuals, really works and what it brings to military practitioners. One of the first modern researchers of this issue was Julien Benda, who raised a question about real value of contribution of public intellectuals and its doubtful character [1]; the failures of the French Plan XVII were attributed to H.Bergson: "Before 1914 France possessed a General Staff worthy to be called Bergsonian. Its doctrine accepted the discredit of intelligence and favoured the cult of intuition. This is a statement which is stupefying and incredible: at first sight it is positively staggering. But after due examination it emerges as a perfectly truthful assertion. And this General Staff of ours forced its conviction to the ultimate limits" [24, p. 33]. Contemporary criticism is aimed to intellectuals who create "intellectual markets" [26]. Besides the public intellectuals, the form of penetration of civil scholarship to military agenda could be considered as institutionalized: for example, numerous US departments of philosophy advertise themselves stating that their graduates are welcomed in CIA; students who received their degrees via ROTC (up to $38 \%$ newly commissioned army officers, 16\% - Navy, 38\% - Air Force) program deliver their intellectual abilities to armed forces. From one side, the professional contribution of officers, trained in humanities and liberal arts are assessed as positive $[11 ; 3$, p. 127; 7]; from the other side researchers note that education system in the USA could be characterized as politically and ideologically biased [10], which can have unpredictable outcomes in the context of active service in the US armed forces; there is no evidence that any serious study was done in this realm.

If to compare influence of two different intellectual mainstreams - analytical and postmodern - the last is overwhelming. It dominates higher educational agenda, because it does not require fundamental special preparation, and it covers general cultural issues. Analytical school of thought is too specific to be popular within society.

The intellectual fashion of Post-Modernism thought is represented in publications of the US military scholars. Traditional academic approach, founded by Sherman Kent [13], Washington Platt [25] etc appeared too conservative for modern challenges [28, p. 407-412], which forced search for new intellectual guidelines and methods, where Post-Modernism with its human/social orientation and variety of interpretations has looked at optimal solution. Open-source papers printed by military scholars do not reflect the attack on the PostModernism by A.Sokal and J.Bricmont $[29 ; 30]$ and other critical reviews, but it does not make the fashion for Post-Modernism more shallow.

Nevertheless, the term "post-modern" is often used not to refer to specific intellectual culture, but just to indicate the contemporary time:

In fact, maybe the conflict in Afghanistan should be labelled "The Post-Modern War Experiment." $[19$, p. 34].

It is too soon to determine whether this development, involving loose networks of combatants who come together for a discrete purpose only to quickly disperse upon its achievement, will prove to be a lasting or completely ephemeral characteristic of postmodern insurgency. Hoffman B. [12, p. 14].

Using this perceptual lens, we can think of warfare as transitioning from the modern to the postmodern era - just as the political and economic systems are doing [3, p. 12].

Necessarily, the lethal operations that are conducted in the physical domain must be, to some degree, supported and reinforced by nonlethal execution in the Human Domain in order to achieve the same success in the Cyber Domain model of the current post-modern terrorist $[6, p .6]$.

The point Clausewitz is at pains to make is that where one combat arm is strong another is weak. Hence, they are interdependent. We like to believe this notion of interdependence is a post-modern phenomenon, but it was apparent in the 19th century and over 2,000 years before to the Romans and Macedonians. [2, p. 77-78].

There is a radical difference between strategy formulated to fight conventional wars and deter nuclear wars and that necessary to conduct armed struggle in the post-modern world [14, p. 12]; The conflicts in Afghanistan and Pakistan do not lend themselves to maneuver warfare, air-centric warfare, or effects-based operations, although each is relevant to the task of developing a theory of postmodern conflict $[14$, p. 21$]$.

More deep understanding of what actually Post-Modernism is shows Colonel Christopher R. Paparone, U.S. Army, retired, an associate professor in the Army Command and General Staff College's Department of Logistics and Resource Operations at Fort Lee, Virginia: "The primary role of the postmodern professional organization is no longer to be a producer of knowledge, stability, and certainty; rather, it is to be a constant organizer in a never-ending condition of complexity - spawning a 
spontaneous approach to replacing tools that are not working" [20, p. 45]; "This sensemaking through high quality human network connections can facilitate improvisation among the members of the logistics community (perhaps this is the principal task of the postmodern logistician)" [21, p. 42]. He proposes his own project of "deconstruction" of metaphors which are used in military language: "This essay has proposed a framework that can assist in needed reflection and help professionals decipher whether specific metaphors are imaginative enough. The mindless tyranny of defunct metaphors in Western military knowledge has already proven its liabilities. Mindfulness of the inherent potential for such domination can serve to motivate imaginative ways to explore breakthrough sensemakings. Such reflection could lead to inventions of breathtakingly rich eloquence in postmodern military discourse" [22, p. 55].

Col. Dale Eikmeier writes about opposition of the post-modern thought to classical mindsets: "They suggest that an enlightenment-age concept based on Newtonian physics, reductive logic, and determinism is too simple to contribute to the understanding of complex adaptive systems in a postmodern age." [9, p. 5]; post-modern thought is clearly attributed to social research: "To bring some context to this abstract proposal, I introduce in this article several design concepts that draw from post-modern philosophical and sociological fields that help us consider whether our Army may inadvertently train to fail, and how it as effectively insulated itself from even questioning these institutionalisms" [32, p. 16].

Military scholars go further when they quote the most significant post-modern writers - M.Foucault, J.Derrida, J.Baudrillard etc, technical terms like "rhizome", "deconstruction", "hermeneutics", Simulacrum etc.

The term "rhizome" is used to refer to a nonconventional system of command "The rhizomatic command system is difficult to attack, just as rhizomatic weeds are difficult to eradicate. General Smith cautions that rhizomes are eradicated by one of three methods: 1) digging them up; 2) poisoning or removing the nutrients from the soil; or 3) penetrating the roots with a systemic poison. Cutting off the visible heads of rhizomes causes them to lie dormant for a time - at best. The attack on a rhizomatic command system is done best from all three directions - operations in each direction being conducted to complement the others. This takes us to the need to conduct a "holistic" war with a total unity of effort" [15, p. 29-30]; Organization to Deal with a "Rhizomatic" Command System and to Generate a Total Unity of Effort. A rhizomatic command system operates with an apparently hierarchical system above ground - visible in the operational and political arenas and with another system centered in the roots underground. It is a horizontal system with many discrete groups. The system develops to suit its surroundings and purpose in a process of natural selection, and with no predetermined operational structure. Its foundation is that of the social structure of its locale. The groups vary in size, but those that survive and prosper are usually small and organized in cells whose members will not necessarily know their relationship with, or the membership of, other cells. A cell will perform a minimum of three tasks: 1) direct and sometimes lead military action; 2) collect and hold resources such as money and weapons; and, 3) direct and sometimes conduct political actions, which can range from bombing train stations, to funding schools, to electioneering. Cells will normally be allowed considerable latitude in the methods they adopt to suit the local circumstances - provided the cell is both successful and no more corrupt than what is condoned by the general movement. In all cases, the need for security is paramount [16, p. 18-19].

Maj. Ben E. Zweibelson, a squadron executive officer for 1/2 Cavalry Regiment, USAREUR, a graduate, of the U.S. Army School of Advanced Military Studies, believes that J.Bodrillard and critical assessment of his concept of simulacre can help to improve US Army training process: "Design" as it relates to military applications has a broad range of conceptual, holistic applications for dealing with complexity, although most services attempt to brand their own design approach for selfrelevant concerns. Army design methodology does not include any of these concepts in U.S. Army doctrine nor does our training strategy specifically reference design theory. However, critical reflection and holistic, systemic approaches might illustrate our training shortfalls. To conduct this inquiry, we draw from philosopher Jean Baudrillard's concept of simulation and simulacra. We also reference sociologists Peter Berger and Thomas Luckmann's collaborative concept of "social knowledge construction," to demonstrate how the Army potentially trains in an approach that is in conflict with what we expect our training to accomplish. Are we spending our energies, resources, and time in training approaches that are detrimental to our overarching goals because they train us in the wrong 
ways? To return to the plot of the science fiction movie quoted at the beginning, shall we swallow the red pill and face uncomfortable truths, or swallow the blue pill and continue enjoying the false realities we create for ourselves through training the force toward national policy goals? [32, p. 16].

LTC Leesa J. Papier, US Army, uses Baudrillard's concept "simulacre" to answer the question how to build a proper strategy against enemy's propaganda: "The democratic system must remove the ambiguity and establish the position of power in that discourse The difficulty of addressing the simulation through discourse is that it regenerates and regenerates its own logic. According to Baudrillard, contradicting one set of signs by producing another set of signs causes the system to disintegrate as it moves further from reality. The USG must establish the reality of the democratic system and remain consistent through truth in its representation of that system. As long as the United States responds reactively with ill-thought 'huh-uh' statements to propaganda designed to denigrate and destroy the democratic system, it is doomed to fail in the long war. The democratic logic is threatened by a simulation, the threat of vanishing in a play of words, risking the real power of the system." [23, p. 55].

J. Derrida's concept of deconstruction, as MAJ Sean C. Chang, US Army, argues, can be used in military operations: "Lastly, the Israeli military employed poststructuralism and the concept of deconstruction in 2002. In an attempt to rearrange space in an urban environment, Israeli military commanders tried to conduct military operations from a deconstructionist perspective, questioning "the relationship between conflict and space." More specifically, this was an attempt to apply Derrida's deconstruction concept by seeing and understanding the relationship of urban battlefield from a different lens. For example, an Israeli commander commented that "defining inside as outside and interiors of homes as thoroughfare [with] soldiers used none of streets, roads, alleys and courtyards that make up the order of the city." In Operation Defensive Shield, the Israeli military demonstrated that poststructuralism and deconstruction are more than just some ivory tower intellectual ideas. These concepts have tangible applicability in real world security and military operations because they offer a credible alternative perspective" [5].

Fashion for post-modernism can seem attractive for researchers who try to find new language for explanation of new realities. Postmodernist thinkers also offer new ways of thinking, which encourage variety of interpretations, focusing on complexities of human-society interaction, and a structure of society in general. The critics of Post-Modernist thought insist that it is irrational and relativist, and military writers partially participate in this counterparadigm.

Being aware of the "Sokal-Brickmont affair" or not, military professional blame postmodernists in fake intellectualism, which hides behind the sophisticated rhetoric: "The IDF's transient embrace of SOD post-modern theories at the expense of traditional principles of war was, arguably, one of the strangest episodes in the history of military doctrine. Using John Ellis' work Against Deconstruction as a backdrop to describe the failings of SOD, Yehuda Wegman writes that SOD was "the image of intelligence and complexity ... the use of rhetorical means in order to create the illusion of intelligent analysis at a time when there was no such analysis." Wegman adds, "The first casualty of the new language was the main principle of war: adhering to the mission" $[18, p .41]$. It is assumed that principles of classic rational thinking are still needed in the modern world: "Amazingly, there were even more officers uncomfortable with questioning their fundamental assumptions about warfare. Today I realize that SAMS could only do so much in introducing different ways to approach the subject. Even after looking into postmodern philosophies, alternative construction of social meaning, and complexity theory and systems thinking, the SAMS curricula could not break away from the demands of the Army in forcing upon us the technically rational paradigm. Thus, after studying how complex adaptive systems resist reductionist understanding and deliberate, rational approaches - we launched into the military decision-making process (MDMP), center of gravity analysis, and backwards, intuitive planning" [17, p. 43]. But the heaviest criticism goes from military academics with highly professional background in humanities, i.e. history: "Although dissimilar in many regards, the post-structuralist theories of Michel Foucault, the deconstructionist notions of Jacques Derrida, and Dominick La Capra's techniques of literary criticism all have one thing in common - they attack some very basic assumptions about what we know and how certain we are about knowing it. To be sure, these theorists often wrap themselves in impenetrable jargon and make some seemingly absurd claims about all knowledge being reducible to a text. Yet, one of postmodernism's central arguments - that the past "as it actually was" is essentially 
irrecoverable and, therefore, unknowable - rings as true as Michael Howard's observation that history is merely what historians write. The postmodernists go one step further, maintaining that historical writing itself, because it involves the personal interpretation of the historian and is therefore an inevitably imperfect rendering of the past, is closer to fiction than nonfiction. Indeed, they have a point ... Indeed, in one sense, the post-structuralists, deconstructionists, and literary critics seem to have hoisted themselves on their own petards. One of the central premises of their argument that the meaning of texts emerges independent of authorial intent gives rise to a philosophical contradiction. After all, if a text can be interpreted in any way the reader desires without regard to authorial intent, then what would prevent historians from reading the texts of the postmodernists in any way that we choose, even in ways that reinforce the validity of historical writing?" [8].

Thus, it is possible to assert that military theorists to some extent reflect the situation in civil intellectual culture: there is a textual evidence of the opposition between Post-Modernists and their more conservative critics. In general, not so many published texts of military scholars deal with so called "cognitive realm", where the likes and dislikes of Post-Modernism can appear, but in some polemic papers it is seen that the debate between Post-Modernists and "conservatives" is much intensive than between their civil colleagues on the "intellectual market". There could be various reasons for that - no fear of a threat to career for established scholars, or just more practical character of the military profession, which requires higher level of responsibility of words and thoughts than, say, a profession of lecturer of literature critic. Anyway, the "Post-Modernist turn" is a response to the challenge of understanding of new realities of war that essentially changed since the end of the Cold War. And its criticism and debates within the military community may contribute not only the development of military theory, but the advance of humanities as well. Since the concepts and mindsets of the leading Post-Modernist thinkers are applied in military theory and practice, this experience should be studied by the specialists in humanities in the first instance - whether this application was done correctly, if not - what interfered and why; which results were received, how adequately the PostModernist agenda was apprehended and, of course, how acceptable the criticism of Post-Modernist thinking in military science was. This analysis can contribute not only military theory, it can be inspirational for the civil thinkers as well.

\section{REFERENCES}

1. Benda, J. (2007). The Treason of the Intellectuals. NJ: New Brunswick, Transaction Publishers.

2. Boothe, L. (2013). King No More. Military Review, May-June.

3. Bunker, R.J. (2009). Reconceptualizing the 2006 QDR Threat Categories. Special Warfare, March-April.

4. Butler, W.F. (1889). Charles George Gordon. London and New York: Macmillan and Co.

5. Chang, S.C. Searching for a Different Understanding of Operational Art. Retrieved from: http://cgsc.contentdm.oclc.org/cdm/ singleitem/collection/p4013coll3/id/3468/rec/1

6. Chapman, H. (2013). A Military Revolution in Human Affairs. Special Warfare, April-June.

7. Cohen, E.A. Neither Fools Nor Cowards. Retrieved from: http://www.wsj.com/articles/SB111594899821632564

8. Echevarria II, A.J. (2005). The Trouble with History. Parameters, Summer, 78-90. Retrieved from: http://ssi.armywarcollege. edu/pubs/parameters/articles/05summer/echevarr.htm

9. Eikmeier, D.C. (2017). The Center of Gravity: Still Relevant After All These Years? Military Review Online Exclusive, May.

10. Gross, P.R., \& Levitt, N. (1994). Higher Superstition. The Academic Left and its Quarrels With Science. Baltimore and London:

The Johns Hopkins University Press.

11. Healey, D.B. (2016). The Humanities and the Army. Army Press Online Journal, 9 February. Retrieved from: http://armypress. dodlive.mil/files/2016/02/Healey-9Feb16.pdf

12. Hoffman, B. (2004). Insurgency and Counterinsurgency in Iraq. Special Warfare, 17 (2).

13. Kent, Sh. (1966). Strategic Intelligence for American World Policy. Princeton: Princeton University Press.

14. Kipp, J.W., \& Grau, L.W. (2011). Military theory, strategy and praxis. Military Review, March-April.

15. Manwaring, M.G. The Strategic Logic of The Contemporary Security Dilemma. Retrieved from: http://ssi.armywarcollege.edu/ pdffiles/pub1091.pdf.

16. Manwaring, M.G. Ambassador Stephen Krasner's Orienting Principle for Foreign Policy (and Military Management) Responsible Sovereignty. Retrieved from: https://ssi.armywarcollege.edu/pdffiles/PUB1104.pdf.

17. Martin, G.M. (2015). Deniers of "The Truth": Why an Agnostic Approach to Warfare is Key. Military Review, January-February. 18. Matthews, M.M. (2009). The Israeli Defense Forces Response to the 2006: War with Hesbollah. Military Review, July-August. 19. Menter, J.M., \& Terrell, B.A. (2013). Modification of the Planning Process for Sustainers Part 1: Design. Army Sustainment. March - April.

20. Paparone, C.R. (2008). Resourcing the Force in the Midst of Complexity: The Need to Deflate the 'ppb' in PPBE. Army Logistician. November - December. 
21. Paparone, C.R. (2008). On Metaphors we are led by. Military Review, November-December.

22. Paparone, Ch.R. (2008). The Nature of Knowledge in the Profession of Military Logistics. Army Logistician. November December.

23. Papier, L.J. Countering Propaganda in the Global War on Terrorism What can a Democracy do? Retrieved from: http://cgsc. contentdm.oclc.org/cdm/singleitem/collection/p4013coll3/id/2451/rec/3

24. Pierrefeu de, J. (1924). Plutarch Lied. New York: Alfred A. Knopf.

25. Platt, W. (1957). Strategic Intelligence Production. Basic Principles. New York: Frederick A. Praeger, Publishers.

26. Posner, R.A. (2001). Public Intellectuals: A Study of Decline. Cambridge, Massachusetts, London, England, Harvard: Harvard University Press.

27. Prince Eugene: General-Philosopher and Art Lover. (2010). Vienna: Belvedere.

28. Shulsky, A.N., \& Schmitt G.J. (1999). Leo Strauss and the World of Intelligence (By Which We Do Not Mean Nous). Leo Strauss, the Straussians, and the American Regime. K.L. Deutsch, \& J.A. Murley (Eds.). Lanham, Boulder, New York, Oxford: Rowman \& Littlefield Publishers, Inc.

29. Sokal, A. (2010). Beyond the Hoax: Science, Philosophy and Culture. Oxford: Oxford University Press.

30. Sokal, A., \& Bricmont, J. (1998). Fashionable Nonsense: Postmodern Intellectuals'Abuse of Science. New York: Picador.

31. Watson, C.A. (2007). Military Education. A Reference Handbook. Westport, London: Praeger Security International.

32. Zweibelson, B.E. (2014). Does the Army Training Strategy Train to Fail? Military Review, January-February.

\section{Лобода Юрій Олександрович}

Студент магістратури кафедри Досліджень війни, кандидат філософських наук, доцент

Лондонський Королівський коледж

Стренд, Лондон WC2R 2LS, Об’єднане Королівство

\section{Loboda Yuriy}

MA student at Department of War Studies, PhD in philosophic sciences, associate professor

King's College London

Strand, London WC2R 2LS United Kingdom

Email: yuriy.loboda@gmail.comＯRCID: 0000-0002-9121-6696

Цитування: Loboda Yu. O. "The Post-Modern Turn" of the US Military Scholars: Shallow, Adherent and Critical? / Yu. O. Loboda // Науково-теоретичний альманах «Грані». - 2018. - Т. 21. - № 7. - С. 77-83.

Citation: Loboda, Yu.O. (2018). "The Post-Modern Turn" of the US Military Scholars: Shallow, Adherent and Critical? Scientific and theoretical almanac «Grani», 21(7), 77-83. 